\title{
Evaluation and Priorities the Promotion Mix Elements for Corporate Banking Customers Using MCDM Methods In Eghtesade Novin Bank
}

\author{
Mohammad Aghaei ${ }^{1}$, Ali lotfi ${ }^{2} \&$ Seyed Mohammad Armakan ${ }^{3}$ \\ ${ }^{1}$ Management study and technology development, faculty of tarbiat modares (TMU), Tebran, Iran \\ ${ }^{2} \mathrm{PhD}$ student of business management at shahre ghods Branch, Islamic Azad University, Tehran, Iran \\ ${ }^{3} \mathrm{PhD}$ student of business management at shahre ghods Branch, Islamic Azad University, Tehran, Iran \\ Correspondence: Mohammad Aghaei, Management study and technology development, faculty of tarbiat \\ modares (TMU), Tebran, Iran. E-mail: m_aghaei@modares.ac.ir
}

Received: April 27, 2016

Accepted: May 11, 2016

Online Published: June 7, 2016

doi:10.5539/mas.v10n9p122

URL: http://dx.doi.org/10.5539/mas.v10n9p122

\begin{abstract}
Among the mixed components of marketing, decisions regarding the promotion tools are very important due to their direct and rapid effect on the target market. With regard to the implementation of new models of banking business in recent years in Iran, the purpose of this research is to priorities the promotion mixas antecedent of integrated marketing communication and strongtools in order to influence the target market of corporative banking customers. The objective of promotion mix in the research emphasized the Increase sales volume, attract new customers, grow market share, enhance brand image, strengthen brand loyalty and increase profitability in the long term. For this purpose, with the help of marketing experts and using models of Multiple Criteria Decision Making (MCDM) methods such as AHP, TOPSIS, SAW, ELECTREand using Entropy weighting methods we have prioritized the components of promotion based on business goals. Finally, according to the fact that using the mentioned models had different results, we used the geometric mean of rates methodin finalized the finding ranking. According to the achieved finding, the different elements in order of priority to meet theconsidered business objectives in this studyinclude sales promotion, direct sales by the account managers, public relations and advertising, Objectives or ratings' criteria.The finding illustrated that although ads are most effective in strengthening the brand, but the other two elements of personal selling and close sales promotion also has the most influence on corporative banking customers.

The results of research shows that the most important instruments in advertising is television, in public relations is holding professional seminars for various industries, in advancing the sales is discount in the loan interest rate and fees, and in the in person sales also is verbal marketing by account managers of corporative banking.
\end{abstract}

Keywords: promotion mix, corporate banking, decision-making multivariable techniques

\section{Introduction}

Traditional marketing studies show that promotional activities have a fast and direct effect on the target market, and it has an important role to inform and enhance brand image and position of products/services in the market and to encourage customers (Lee, 2002) and ultimately it affects thecustomer buying behavior in the target market (Haresty, 2003). The other applications of promotion mix are using customer feedback to design products and services, changes in consumer purchasing behavior and communicate with customers due to its limitations such as high cost (Hsu, Tsai \& Chiang, 2009).

Promotion elements as an essential part of the marketing integration arethose that have a direct and quick impact on the target market. Due to this fact, the choice of such activities is an important decision. Promotion is basically the same as communication. Promotion is considered as a process that through it the company information is transferred to the target market in order to help its position or products in the preferred locations and to get a favorable response from the customers (Lopez, 2002; Solomon, 2000). The marketing manager should choose a combination of various instruments of promotion mix that will lead to organization goals and more efficiency with a method that has a least cost.

For this purpose we should have a promotion plan (Berger, 2001). In this article, in order to have an influence and effect on the target markets of corporative banking, we have investigated and prioritized the promotion mix 
for the corporative banking customers in EGHTESADE NOVIN bank. The products and services of corporative banking in EGHTESADE NOVIN bank are presented for great customers with the focus on experts of the relationships with customers.

Description of promotion mix elements asantecedent of IMC in corporate banking.

The general concept of promotion includes three elements: Objectives of promotion combination, activities and instruments of promotion, and mixed budget of promotion. The allocation of funds for the promotion is fundamental and has a determinant aspect (Herrera et al., 2002). In the past, the judging-oriented and data-oriented methods often were used to determine the most suitable promotion instruments, while satisfaction of the considered marketing function according to the fund limitations is a profound necessity (Belch, 2004), (Hsu, Tsai \& Chiang, 2009).

The objectives of promotion are: The highest influence on the target market segments with the lowest cost (McNamee, 1989), develop a potential awareness of the new product or service, refreshing customers' memories of existing organizations, a brand product, or service by reminding them, creating aimed attitude to the different segments of the market, obtaining the desired sales volume and sending signal to their competitors (Herrera, 2002), increasing sales volume, strengthen customer loyalty, encourage customers to change their participation and strengthen the brand (MELA,1998). In one of the studies, the promotionmix based on the company's business goals such as increasing sales, attract new customers, grow market share, enhance brand image, strengthen brand loyalty and increase profitability in the long run have been prioritized (Hsu, 2008).

Promotionmixes a series of promotion activities, including advertising, sales promotion, publicrelations and personal selling that the company applies them in order to promote selling and achieve other goals of marketing. The various encourage activities have their own advantages and disadvantages and have their own instruments (Solomon, 2000).

1) Advertisement: Marketing manager should have a total control over what the message should say, when it should be offered and those who are targeted (Kotler, 1998). Advertising is an impersonal presentation (ideas, goods, or services that is supported by a known sponsor. Through advertising, the customers are confident about the new product (Herrera et al., 2002).

2) Sales promotion: This method provides some motives for retailers and customers to buy the product and creates motivation among retailers and customers. It encourages the immediate and urgent purchases and also testing the new products (Kotler, 1998). Sales promotion includes a number of techniques designed to estimate the customer awareness of his interest in the company's the product. So, directly or indirectly stimulates to purchase or use the product in the short term (Herrera et al., 2002).

3) Personal selling: The personal selling transfers persuasive message or series of messages to target customers by a person who is paid by the company. Unlike other promotional elements, the mutual feature is between the seller and the customer who is coming (Herrera et al., 2002). Direct contact with the customer gives the seller the opportunity to be flexible and adjust his sales message according to customer needs (Kotler, 1998).

4) Public relations: Public relations is all about creating and maintaining a good relationship with the people. This instruments cover customers and suppliers, public opinion and anyone else who is associated with company trading (Herrera et al., 2002; Kotler, 1998).

5) Direct marketing: In direct marketing, products/services are directly set up for the target market. So that through it, timely purchase request, selective calling information, saving time and increasing comfort is possible (Reardon, 2002).

The need for greater and more effective customer orientation and the separation of retail banking and corporate banking activities from the second half of the 90s was considered by bank managers in the world. Restructuringthe functional structure to have market-oriented and customer-oriented structures in order to respond effectively to the dynamics and competitive environment and expectations of customers in the banking industry in recent years with a little delay have been considered by the country bank managers. Corporate banking goals are: Increasing the volume of business in the field of corporate banking by referring to new and potential clients, increase corporate customers satisfaction and increase revenue of the corporate bankingarea. Corporate banking products range from the traditional banking services as well as certain corporate banking services. In this structure, the corporate banking customers are separated from the retail and dedicated customers and all of their banking affairs are accomplished by account managers or customer relationship managers. Account manager is a trained person and specializes in all the aspects of banking and finance affairs of the great 
customers and also is considered as the special sales force of corporate banking (Laurentis, 2005).

\section{Methodology}

This research in terms of the objective is a part of applied researches and in terms of the method is the descriptive and field research. In this research in order to determine the optimal promotionmixthemultiple criteria decision-making methods were used. In these decisions, instead of using one criterion of optimality, several criteria may be used (ASGHARPUR 1, 1377). The research questionnaire was given to 15 people of marketing certified experts of corporate banking customers in EGHTESADE NOVIN bank. Application of multi-criteria decision-making models (MCDM) is when the decider due to multiple factors chooses one of them or rates them. In this paper, firstly the analytic hierarchy process (AHP) and then testing theother methods such as TOPSIS, SAW, and Electre were used by the entropy weighting method to rank the criteria and options. The promotion elements in this research are: Advertising, public relations, sales promotion and personal sellingthat in this regard, account managers play a central role in customer relationship management. Also in order to evaluate elements the criteria used in similar studies such as increased sales volume, attract new customers, grow market share, enhance brand image, strengthen brand loyalty and increase profitability in the long term were used. Based on this fact the conceptual model of research is shown in the Figure 1.

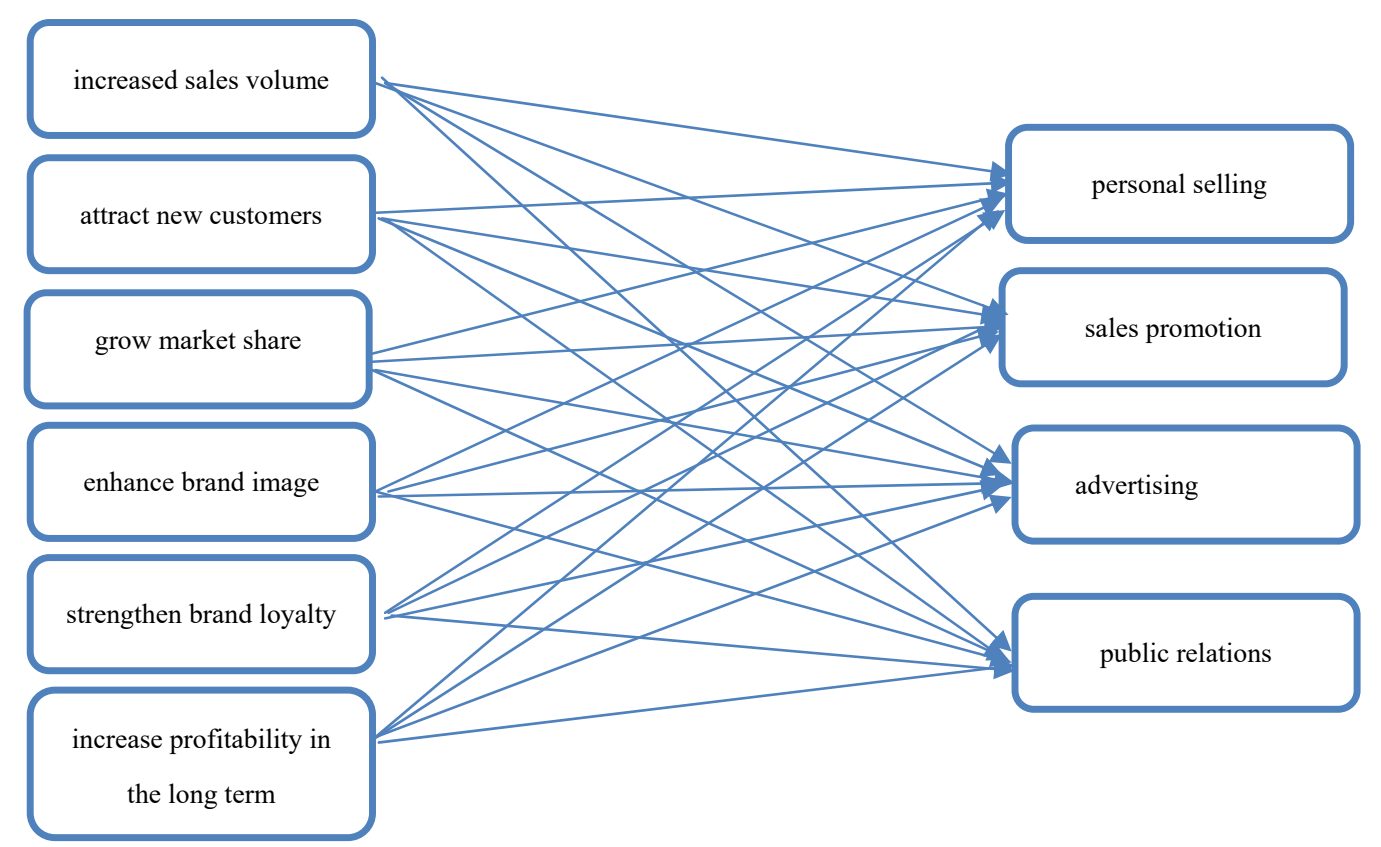

Figure 1. Promotion mix elements as conceptual model

In another part of the questionnaire the instruments of elements of promotion were identified and were ranked by experts with the aim of the most effectiveness in the target market in order to achieve the marketing objectives. Analytic Hierarchy Process was invented in 1980 by Thomas hour. This method is used to solve the complex issues and multi-criteria decisions. This method is conducted in four phases of establishment of hierarchical tree, paired comparisons tables, investigating the incompatibility rate and average of experts' opinions (Jyotirmoy, 2010). TOPSIS method was developed by Huang and ion in 1981 to rank and select the possible solution through measuring the intervals. According to main principle of this method, the best solution is closest to the positive ideal solution and the greatest distance from the negative ideal solution. In this method, after un-scaling the evaluation matrix of calculation the weights of indicators by entropy, calculating the intervals and ranking the alternatives is accomplished (Zhang, 2011). Entropy techniques a method to find the weight of indicators. The idea of this method is that if the dispersion in the values of an indicator increases that indicator will have more importance. The SAW technique that is used in this research is the simple weighted sum model that is one of the easiest multiple attributes generalization methods. By calculating the weights of the indicators, this method can be easily used. In the SAW method an option is selected that their result of the sum of unscaled values weight is more than the other options. Another method used in this research is the Electretechnique. This method was developed in the late 1980s. The basis of this model is the unranked relations it means that necessarily does not 
lead to the ranking of alternatives. It may eliminate some options and introduce the best alternatives. In this study, the MCDM engine software is used to rank the promotion mix. This software has the ability to solve the following methods: Calculating the weights of indicators with Entropy techniques, ranking the alternatives by TOPSIS, SAW, and Electretechniques (MOMENI, 1394). Finally, according to the fact that the various techniques are different, so the mean method is used to obtain a single result (MOMENI, 1385).

\section{Data Analysis}

The promotion elements special for the corporate banking customers using paired comparison matrix of AHP method and then using the decision matrix, weights obtained from Electre, TOPSIS and SAW techniques were prioritized in two ways with the obtained weights in the paired comparison matrix or the obtained weights with the software by entropy method that are shown in Tables 1 .

Table 1. Ranking promotion mix by AHP

\begin{tabular}{|c|c|c|c|c|c|c|c|c|}
\hline business objective & $\begin{array}{l}\text { increased } \\
\text { sales } \\
\text { volume }\end{array}$ & $\begin{array}{l}\text { attract } \\
\text { new } \\
\text { customers }\end{array}$ & $\begin{array}{l}\text { grow } \\
\text { market } \\
\text { share }\end{array}$ & $\begin{array}{l}\text { enhance } \\
\text { brand } \\
\text { image }\end{array}$ & $\begin{array}{l}\text { strengthen } \\
\text { brand } \\
\text { loyalty }\end{array}$ & $\begin{array}{l}\text { increase } \\
\text { profitability } \\
\text { the long term }\end{array}$ & in & \\
\hline Weights & 0.2551 & 0.1868 & 0.1614 & 0.1528 & 0.1140 & 0.1299 & score & rank \\
\hline Advertising & 0.2261 & 0.2002 & 0.1596 & 0.2982 & 0.1294 & 0.1839 & 0.205 & 4 \\
\hline public relations & 0.1973 & 0.2207 & 0.2522 & 0.2354 & 0.1929 & 0.1854 & 0.348 & 2 \\
\hline personal selling & 0.2607 & 0.3216 & 0.3101 & 0.2084 & 0.2948 & 0.3055 & 0.448 & 1 \\
\hline \multirow[t]{2}{*}{ Sales promotion } & 0.3158 & 0.2575 & 0.2781 & 0.2580 & 0.3829 & 0.3252 & 0.372 & 3 \\
\hline & 1.000 & 1.0000 & 1.0000 & 1.0000 & 1.0000 & 1.0000 & & \\
\hline
\end{tabular}

According to the ranking results based on AHP, the importance of the promotion elements based on the considered criteria is as follows: Personal selling by account managers, public relations, sales promotion and advertising. In other words, in the promotion mix of the corporate banking customers the account managers has the most role and advertising has the least role.

Table 2. Ranking promotion mix by topsis

\begin{tabular}{lllllllll}
\hline business objective & $\begin{array}{l}\text { increased } \\
\text { sales } \\
\text { volume }\end{array}$ & $\begin{array}{l}\text { attract } \\
\text { new } \\
\text { customers }\end{array}$ & $\begin{array}{l}\text { grow } \\
\text { market } \\
\text { share }\end{array}$ & $\begin{array}{l}\text { enhance } \\
\text { brand } \\
\text { image }\end{array}$ & $\begin{array}{l}\text { strengthen } \\
\text { brand } \\
\text { loyalty }\end{array}$ & $\begin{array}{l}\text { increase } \\
\text { profitability in } \\
\text { the long term }\end{array}$ & score & rank \\
\hline Weights & $\mathbf{0 . 0 8 6 7}$ & $\mathbf{0 . 0 9 3 4}$ & $\mathbf{0 . 1 4 9 4}$ & $\mathbf{0 . 0 4 8 7}$ & $\mathbf{0 . 4 2 7 7}$ & $\mathbf{0 . 1 9 4 1}$ & & \\
Advertising & 0.2261 & 0.2002 & 0.1596 & 0.2982 & 0.1294 & 0.1839 & & \\
public relations & 0.1973 & 0.2207 & 0.2522 & 0.2354 & 0.1929 & 0.1854 & $\mathbf{0 . 2 6 1 1}$ & $\mathbf{3}$ \\
personal selling & 0.2607 & 0.3216 & 0.3101 & 0.2084 & 0.2948 & 0.3055 & $\mathbf{0 . 6 7 4 7}$ & $\mathbf{2}$ \\
Sales promotion & 0.3158 & 0.2575 & 0.2781 & 0.2580 & 0.3829 & 0.3252 & $\mathbf{0 . 9 3 2 4}$ & $\mathbf{1}$ \\
& 1.000 & 1.0000 & 1.0000 & 1.0000 & 1.0000 & 1.0000 & & \\
\hline
\end{tabular}

According to the above table, the ranking of the promotion elements in TOPSIS technique usingthe imported weights and weights that were obtained from the entropy, all were the same. And they are respectively as follows: Sales promotion, account managers, public relations and advertising.

Table 3. Ranking promotion mix by SAW

\begin{tabular}{lllllllll}
\hline business objective & $\begin{array}{l}\text { increased } \\
\text { sales } \\
\text { volume }\end{array}$ & $\begin{array}{l}\text { attract } \\
\text { new } \\
\text { customers }\end{array}$ & $\begin{array}{l}\text { grow } \\
\text { market } \\
\text { share }\end{array}$ & $\begin{array}{l}\text { enhance } \\
\text { brand } \\
\text { image }\end{array}$ & $\begin{array}{l}\text { strengthen } \\
\text { brand } \\
\text { loyalty }\end{array}$ & $\begin{array}{l}\text { increase } \\
\text { profitability in } \\
\text { the long term }\end{array}$ & score & rank \\
\hline Weights & $\mathbf{0 . 0 8 6 7}$ & $\mathbf{0 . 0 9 3 4}$ & $\mathbf{0 . 1 4 9 4}$ & $\mathbf{0 . 0 4 8 7}$ & $\mathbf{0 . 4 2 7 7}$ & $\mathbf{0 . 1 9 4 1}$ & & \\
Advertising & 0.2261 & 0.2002 & 0.1596 & 0.2982 & 0.1294 & 0.1839 & $\mathbf{0 . 4 9 9 9}$ & $\mathbf{4}$ \\
public relations & 0.1973 & 0.2207 & 0.2522 & 0.2354 & 0.1929 & 0.1854 & $\mathbf{0 . 6 0 4 6}$ & $\mathbf{3}$ \\
personal selling & 0.2607 & 0.3216 & 0.3101 & 0.2084 & 0.2948 & 0.3055 & $\mathbf{0 . 8 6 0 3}$ & $\mathbf{2}$ \\
Sales promotion & 0.3158 & 0.2575 & 0.2781 & 0.2580 & 0.3829 & 0.3252 & $\mathbf{0 . 9 5 9 3}$ & $\mathbf{1}$ \\
\hline
\end{tabular}




$\begin{array}{llllll}1.000 & 1.0000 & 1.0000 & 1.0000 & 1.0000 & 1.0000\end{array}$

The results of using the SAW technique similar to the TOPSIS technique have presented the same results. In the following table, ranking is conducted by the Electre technique.

Table 4. Ranking promotion mix by electre

\begin{tabular}{lllll}
\hline & Advertising & public relations & personal selling & Sales promotion \\
\hline Advertising & $\mathbf{0}$ & $\mathbf{0}$ & $\mathbf{0}$ & $\mathbf{0}$ \\
public relations & $\mathbf{1}$ & $\mathbf{0}$ & $\mathbf{0}$ & $\mathbf{0}$ \\
personal selling & $\mathbf{1}$ & $\mathbf{1}$ & $\mathbf{0}$ & $\mathbf{0}$ \\
Sales promotion & $\mathbf{1}$ & $\mathbf{1}$ & $\mathbf{1}$ & $\mathbf{0}$ \\
\hline
\end{tabular}

According to the above table and using thedefinedweightsaccording to experts view, Public relations, personal selling and sales promotion are superior to advertising. Also Personal selling and Sales promotion have a same level of superiority to public relations. Therefore, Sales promotion and personal selling are superior to public relations and advertising. Also, according to the results of Electre techniques with entropy weights in addition to the above-mentioned results, the superiority of sales promotion to personal selling is shown. Therefore, based on Electre technique with entropy method, the promotion elements are: Sales promotion, personal selling, public relations and advertising.

In Table 5, in order to achieve a single result from the ranking results of the various ranking methods the geometric mean method is used. As it is seen, the promotion elements are: Sales promotion, personal selling, public relations and advertising, Sales promotion and personal selling by account managers together have the utmost importance.

Table 5. Ranking promotion mix by using multi-criteria decision-making methods (MCDM)

\begin{tabular}{llllll}
\hline Methods & AHP & Topsis & SAW & Electre & geometric mean of rates \\
\hline Advertising & 4 & $\mathbf{4}$ & $\mathbf{4}$ & $\mathbf{4}$ & $\mathbf{4 . 0 0}$ \\
public relations & 2 & $\mathbf{3}$ & $\mathbf{3}$ & $\mathbf{3}$ & $\mathbf{2 . 7 1}$ \\
personal selling & 1 & $\mathbf{2}$ & $\mathbf{2}$ & $\mathbf{2}$ & $\mathbf{1 . 6 8}$ \\
Sales promotion & 3 & $\mathbf{1}$ & $\mathbf{1}$ & $\mathbf{1}$ & $\mathbf{1 . 3 2}$ \\
\hline
\end{tabular}

In down figurepromotion mix andeach of the elements of the promotion various instruments are prioritized according to experts view in order to achieve the considered objective that is the level of effectiveness on the target market. 


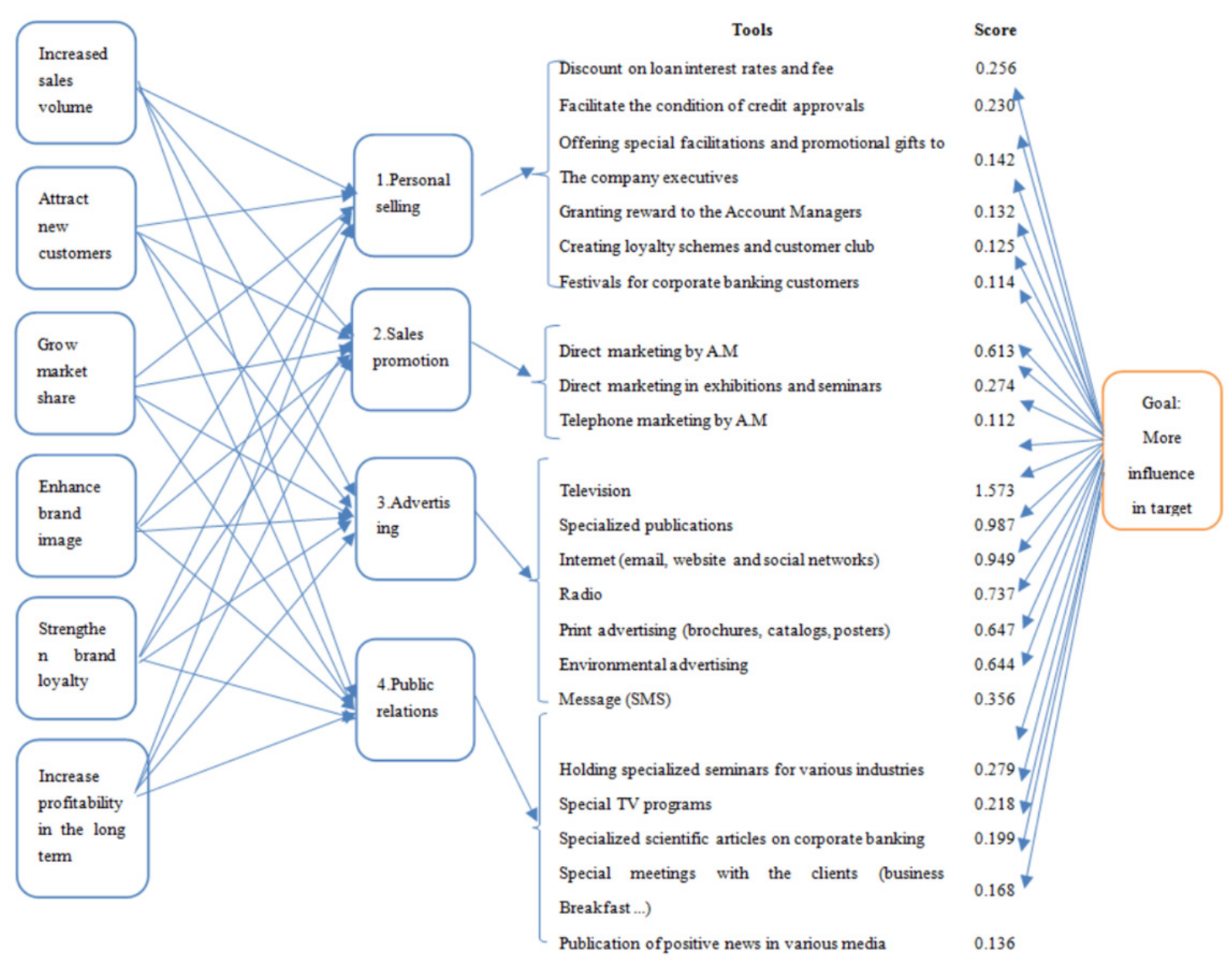

Figure 2. The level of effectiveness on the target market

As it is shown, among the public relations instruments there is holding specialized seminars for various industries, among the sales promotion instruments discount on loan interest rates and fees, and among the personal selling tools also the personal marketing by the account managers of corporate banking is a priority. Among the advertising tools still television advertising for corporate banking customers is a priority. Butadvertising importance according to various criteria considered in this study is in the last place.

\section{Finding and Discussions}

According to the survey of bank marketing certified experts at EGHTESADE NOVIN Bank and using different techniques of decision MADM, the results indicate that integrate elements of promotion for corporate banking customers in order of importance in meeting the objectives of research in general and by merging the results are: Sales promotion, personal selling that is done in EGHTESADE NOVIN bank particularly in corporate banking offices with a focus of account managers, public relations and eventually advertising. In different techniques of prioritization, only in AHP method the account managers are more important than Sales promotion, but in other methods (TOPSIS, SAW, ELECTRE) with the close interval the Sales promotionis more important than personal selling. This ranking has been conducted based on the goals and standards of the research from one of the studies of (Hsu, 2008) that are: Increase sales volume, attract new customers, grow market share, enhance brand image, strengthen brand loyalty and increase profitability in the long term. This issue shows that technical criteria are more considered by the corporate managers than the quality of relationship with the customer. The results of prioritization of each advertising tools based on the objective of influencing the target market indicate that in sales promotion discount on the interest rate and fees, is considered by the customers more than the facilitation of credit approvals, and granting special privileges to managers of target companiesand other instruments are the next priorities. In personal selling also personal marketing by the account managers and visiting the target companies shows more influence. Among the advertising tools the specialized publications after television has the most effectiveness and other advertising tools are the next priorities. Among the public relations instruments 
holding specialized seminars for target industries from the view of certified experts of marketinghave allocated the highest priority to itself.

\section{Results and Conclusion}

In the current market of Iran banking system, using various methods to sales promotion such as a discount on the interest rate of the facilities or facilitate the securities (using the securities type2 rather than type1) it certainly would be desirable for corporate banking customers. But in order to ensure a sustainable profitability that has been one of the evaluation criteria in this research, account managershave a unique role in managing customers' expectations and loyalty. In other words, although the tools of sales promotion are attractive to the customers, but the role of account managers in customer satisfaction and quality of communication with the customers can be effective in moderating the expectations of our customers. On the other hand, the results of this research have shown that advertising that is the costly part of the promotional activities of any organization has known as the least effective element of promotion in the market of corporate banking in this research. This issue can reminds us of the lower importance of advertisement in B2B business compared to the other elements of promotion and also endorses the role of the quality of relationship with the customer and sales promotion instruments.

\section{Suggestions for the Future Researches}

In the end, it is recommended that with the emergence of new advertising tools such as the Internet and social networks and also creating new business models of banking in Iran, the promotion mix model of retail, private and corporate banking in Iran should be evaluated and the optimized model must be proposed.

\section{References}

Belch, G. E., \& Belch, M. A. (2004). Advertising and Promotion (6th Ed.). McGraw-Hill, NY.

Berger, P. D., \& Bechwati, N. N. (2001). The allocation of promotion budget to maximize customer equity. Omega, 29, 49-61.

Brown, R. E. (2002). Electric Power Distribution Reliability. Marcel Dekker Inc., NY.

Fam, K. S., \& Merrilees, B. (2001). What do excellent service promoters do differently? The Service Industries Journal, 21(4), 1-16.

Giacomo, D. L. (2005). Strategy and organization of corporate banking. Springer.

Hardesty, D. M., \& Bearden, W. O. (2003). Consumer evaluations of different promotion types and price presentations: The moderating role of promotional benefitlevel. Journal of Retailing, 79, 17-25.

Herrera, F., López, E., \& Rodríguez, M. A. (2015). A Linguistic Decision Model for Promotion Mix Management Solved with Genetic Algorithms, supported by DGICYT PB95-0. http://dx.doi.org/10.1016/S0165-0114(01)00254-8

Jyotirmoy, D., Pratap, K. J. M., \& Gopal, C. M. (2010). Prioritization of rural roads: AHP in group decision. Engineering, Construction and Architectural Management, 17(2), 135-158.

Kotler, P. (1998). Marketing (4th Ed.). Prentice- Hall.

Kotler, P., \& Keller, K. L. (2006). Marketing Management (12th Ed.). Prentice Hall, NY.

Lee, C.W. (2002). Sales promotions as strategic communication: The case of Singapore. Journal of Product and Brand Management, 11(2), 103-114.

McNamee, P. (1989). Management Accounting: Strategic planning andmarketing. Heinemann, London.

Mela, C. F., Gupta, S., \& Jedidi, K. (1998). Assessing long-term promotional influences on market structure. International Journal of Research in Marketing, 15, 89-107.

Park, C.W., \& Zaltman, I. (1987). Marketing Management. Dryden Press, Hinsdale, Illinois.

Reardon, J., \& McCorkle, D. E. (2002). A consumer model for channel switching behavior. International Journal of Retail and Distribution Management, 30(4), 179-185.

Slater, S. F., \& Narver, J. C. (1995). Market Orientation and the Learning Organization. Journal of Marketing, 59, 63-74.

Solomon, M. R., \& Stuart, E.W. (2000). Marketing. Prentice-Hall.

Tsuen-Ho, H. A., Tsung-Nan, T. B., \& Pei-Ling, C. A. (2009). Selection of the optimum promotion mix by integrating a fuzzy linguistic decision model with genetic algorithms, T. H. Hsu et al. Information Sciences, $179,41-52$. 
Zhang, H., Gu, C., Gu, L., \& Zhang, Y. (2011). The evaluation of tourism destination competitiveness by TOPSIS and information entropy eA case in the Yangtze River Delta of China. Tourism Management, 32, 443-451.

\section{Copyrights}

Copyright for this article is retained by the author(s), with first publication rights granted to the journal.

This is an open-access article distributed under the terms and conditions of the Creative Commons Attribution license (http://creativecommons.org/licenses/by/3.0/). 